\title{
TRIPLE -E VESSELS: TONNAGE MEASUREMENT AND SUEZ CANAL DUES ASSESSMENT
}

\author{
ELSAYED HUSSIEN GALAL \\ Vice director of Suez Canal transit department \\ Email: galallelsayed@gmail.com
}

\begin{abstract}
Container industry is growing faster than GDP; Shipping lines always attempt to augment efficiency by reducing cost and by attracting larger volumes of containers. As a result, rising container freight rates leads to an increase of the economic scale of the lines that have been driven, by building mega ships and making more efficient port calls. In 2011 Maersk line ordered up to 20 new "Triple- E "Class of container vessels to be delivered between 2013-2015. This class of mega container vessels has its way through Suez Canal. Other companies like CMAand CGM also ordered this type of mega container vessels in order to reach higher profits due to the achieved economic scale. It is believed that 20000 TEU could be the next target size. Present mega container fleet of vessels and any future potential vessel capacity demand an expansion for Suez Canal route to handle vessels larger than 18000 TEU. This will put Suez Canal route in strong competitive position. Meanwhile Panama Canal will not be able to handle vessels larger than 12600 TEU even after its expansion in 2015.
\end{abstract}

Keywords - Triple - E Vessels - Tonnage measurement - Suez Canal rules.

\section{INTRODUCTION}

Various types of vessels transit Suez Canal. On top of these ships, come container vessels which represent $56 \%$ of total Suez Canal net tonnages and $60 \%$ of Suez Canal total revenues. Specifications and characteristics of Triple $-E$ vessels have been studied. It is worth mentioning that Triple-E vessel pay about one million US dollars as transport dues when transiting Suez Canal. At the same time the cost of TEU transiting Suez Canal for this type of vessel is less than small types such as New Panamax (12500 TEU ) or New -Post Panamax (15000 TEU), thereby achieving high economic scale. This paper mainly highlights various methods of tonnage measurements in general and various methods of tonnage measurements for Suez Canal in particular.

\section{CONTAINER VESSELS EVOLUTION}

Container ships carry more than $95 \%$ of the world's manufactured goods.In the last decades container vessels became larger carriers trying to achieve high economic scales by increasing the container vessels capacity and consequently the emergence of socalled mega container vessels or ultra-large container vessels has taken place. This new generation of ships is called "Triple-E". "Triple-E" vessels have emerged taking into account the following specifications:

- Energy efficiency.

- Economics of scale.

- Environmental improvements, reducing Co2 emission by $50 \%$ per container carried.

\section{Larger Vessels}

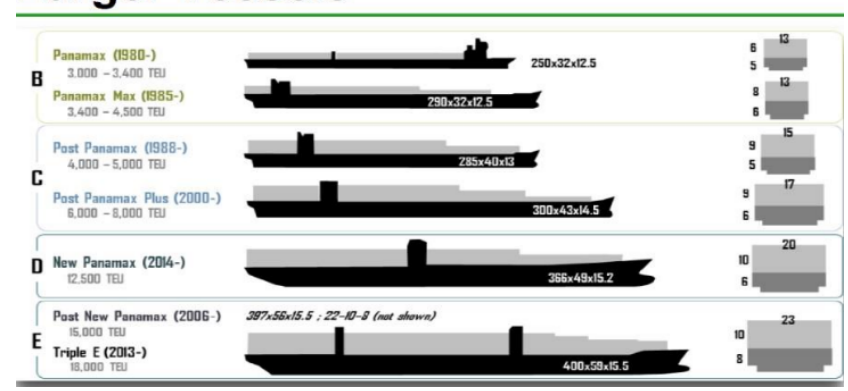

Fig .1. Evolution of Container ships

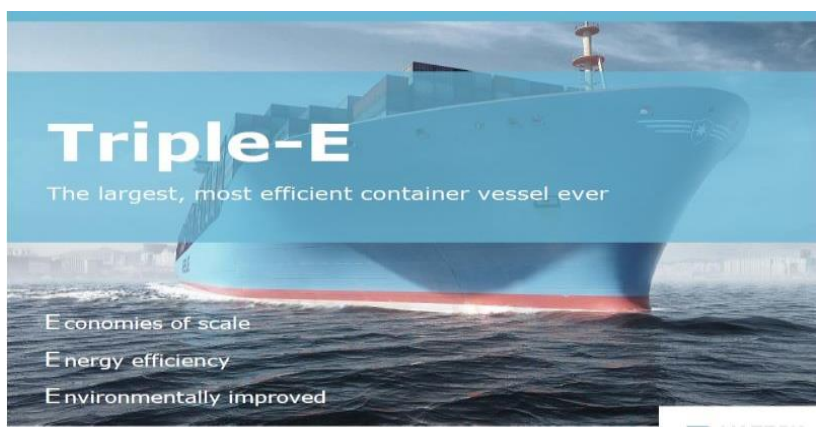

Fig .2. TRIPLE-Class 
Such ships need new ports and container terminals with high specifications and sustainable maritime system. Nowadays, this type of vessels uses ASIAEurope lane through Suez- Canal

\section{TRIPLE- E CLASS IN FIGURES}

Its length is approximately $400 \mathrm{~m}$, its width is approximately $59 \mathrm{~m}$, its draught is about $14.5 \mathrm{~m}$ and its capacity is 18200 TEU (on deck approx. 10600 TEU in holds $7600 \mathrm{TEU})$. Its displacement is 55000 tons. A reefer container's capacity is $600 \mathrm{TEU}$. Its height is $73 \mathrm{~m}$. Its maximum speed is $23 \mathrm{knots}$, average speed is approximately 17-18 knots. Rows in hold/ on hatches are about $21 / 23$, Tiers in hold/ on Hatches are about $11 / 10$.

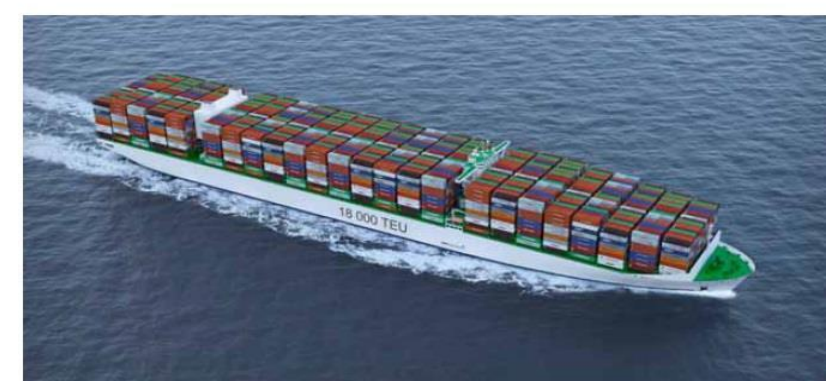

Fig .3. TRIPLE-Class

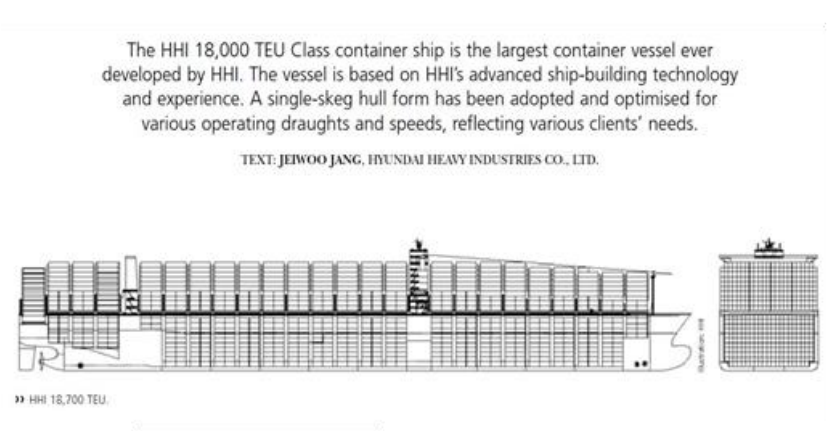

Fig .4. Longitudinal Section of 18000 TEU Ship

The economics of ship size are the driving force for increasing numbers of containers transported. The aforementioned dimensions of "triple- E" vessels are outside the ability of Panama Canal dimensions even after its recent expansion project. Also it has 30\% less power per ton displacement than the other vessels (EMMA MAERSK, MARCO POLO). This is mainly because the "triple- E" vessels will be sailing at the utmost power speed because it has a full Ushaped body and is more spacious than traditional containerships; accordingly one extra row of containers has to be accommodated. The engine room has been put at the rear of the ship instead of the middle, so it is able to fit in more containers behind the navigation bridge and in the hull.

\section{ENERGY EFFICIENCY OF TRIPLE-E VESSELS}

A waste heat recovery system helps propel the ship by capturing energy from the engine's exhaust gas. This cuts fuel by up to $10 \%$. The, energy is also used to produce electricity for the onboard accommodations. The waste heat recovery system on "Tripe - E" vessels has allowed to use a smaller and less energy, consuming main engine speeds in the range of 20- 25 knots. Now, these speeds had dropped to 15-17 knots lesser than it was commonplace 5 years ago,

\section{ENVIRONMENTAL IMPROVEMENT}

Triple-E" vessels are a combination of carefully thought-of technological and ecological solutions, as well as the result of many years of engineering work. They will enhance the ecological solutions and performance.

Better fuel efficiency may be the easiest way to cut down on both air pollution and greenhouse gases. Thus, "Triple-E" vessel innovative design and technological features will help reduce its $\mathrm{CO} 2$ emissions by more than $50 \%$ for every container it moves. Also it has a waste heat recovery system that reduces fuel consumption. Emissions of air pollutants from the shipping sector have increased substantially in the last two decades, contributing to both climate change and air pollution problems. In 2007 shipping sector was responsible for $3.3 \%$ of global carbon dioxide emissions. This sector has contributed to the growing of emissions by $4 \%$ per year over the next decade .If ships reduced their speed by $10 \%$, which is known as "slow steaming ", they could cut and reduce carbon footprint.

\section{PROBLEMS FACING TRIPLE- E VESSELS}

The greater outreach required to service the ship's extra row of containers will mean longer booms. The booms also must be located at a greater height than the height of the ship's container stacks which also creates a number of new stresses. The wind forces on the crane will be higher which has an impact on wheel loads [1].

The capital cost per TEU moved has increased even, considering the increase in slot size of the vessels. 
Furthermore, due to the increase in transportation duration, the capital cost and insurance of goods transported have gone up. Furthermore the cost increase could be influenced by the time-length taken by goods that need longer to get from the world's production centers to the markets. Goods that move faster cost less. Shipping lines are demanding ever shorter port stay in order to make the economies of scale work. Longer vessels of 400 yards (such as Maersk Line's "Triple-E" class) will lead to more berth wastage to handle efficiently. High port productivity and reliability are essential to enable carriers to operate within schedules. The bigger the ship, the greater the cost of hours lost in port, and an increased port stay is a diseconomy of scale [2].

\section{IMPORTANCE OF CONTAINER SHIPS IN SUEZ CANAL}

The Suez Canal plays a pivotal role in today's global container shipping network, particularly in accommodating vessels that sail on the important. ASIA- EUROPE trade lane. Container ships accounted for about $56 \%$ of Suez Canal total net tonnages and $60 \%$ of total revenues. The charge of containerized cargo also is still rising. The number of TEUs transiting the Suez Canal is still growing, it has reached ( 42.1 million TEUs ) in 2014, (38.2 million TEUs ) in 2013 and (37.7 million TEUs) in 2012 . The following data illustrates the importance of container vessels traffic through Suez Canal (as stated on tables 1 \& 2).

Table 1. Number of container ships and its net tonnages

(2010-2014) : Source: Suez Canal Authority

\begin{tabular}{|c|c|c|c|c|}
\hline Year & $\begin{array}{c}\text { No. of Container } \\
\text { vessels }\end{array}$ & $\begin{array}{c}\text { Container ships net } \\
\text { tonnages (million tons) }\end{array}$ & $\begin{array}{c}\text { Total net tonnages of ships in } \\
\text { Suez Canal (Million Tons) }\end{array}$ & $\begin{array}{c}\text { Ratio of net tonnage of } \\
\text { container ships\% }\end{array}$ \\
\hline 2010 & 6852 & 465.7 & 846.4 & 55 \\
\hline 2011 & 7178 & 519.3 & 928.5 & 55.9 \\
\hline 2012 & 6332 & 507.1 & 915.5 & 55.5 \\
\hline 2013 & 6014 & 508.2 & 962.7 & 55.7 \\
\hline 2014 & 6129 & 536.3 & & 5.5 \\
\hline
\end{tabular}

Table 2. Containerized Cargo in Suez Canal : Source: Suez Canal Authority

\begin{tabular}{|c|c|c|c|}
\hline Year & Containerized cargo (million tons) & Total Cargo (Million Tons) & Ratio of containerized Cargo \% \\
\hline 2010 & 367.0 & 646.1 & 56.8 \\
\hline 2011 & 397.2 & 691.8 & 53.8 \\
\hline 2012 & 398.0 & 739.9 & 53.8 \\
\hline 2013 & 406.1 & 754.5 & 52.9 \\
\hline 2014 & 435.0 & 822.3 & \\
\hline
\end{tabular}

Comparing containerized cargo with the total cargo in Suez Canal, we find it ranging between $54 \%$ to $57 \%$ as stated in table 2.

\section{IMPORTANCE OF TONNAGE IN MARITIME WORLD}

Maritime institutes and departments of ship engineering in Egyptian Universities does not give sufficient importance to the study of ship tonnage measurement rules in spite of its importance in maritime world. The tonnage of a ship has become important as one of its defining characteristics. 
This paper is intended to define and point out briefly some of the ways that tonnage factors influence ship design. It also sheds light on how tonnage factors affect the financial responsibility of ship-owners who pay dues in accordance with the amount of net tonnage, gross tonnage or net registered tonnage.

Practically all seagoing merchant vessels operating on the open seas, bays, rivers, lakes and waterways are measured for the assignment of national gross and net registered tonnages. Also vessels intending to transit Suez Canal and Panama are measured according to the rules of the respective canal authorities. IMO rules refer always to tonnage base to its laws. Harbors and waterways dues are depending on net tonnage base or gross tonnage. Light house dues, pilotage dues, dry dock dues, wharves dues and similar facilities throughout the life of the vessel depend on its tonnage. Also, there is a correlation between tonnage and the balance and the safety rules of a ship.

The tonnage figures are used for statistics in maritime trade and for charging taxes. They are also used for comparison of national fleets, framing of policies on trade of shipping, granting of subsidies, comparison of shipbuilding, scrapping, regulatory application basis for manning, registration and survey charges, insurance premium and limitation liability in cases of pollution. For vessel registration, tonnage indicators must be offered. Shipping tonnage was a useful indicator of a country's commercial strength. It also indicates the physical carrying capacity of a ship as well as the comparison of trade and movement of goods. Tonnage has been used to indicate the relative magnitude of ships for centuries.

\section{EVOLUTION OF TONNAGE MEASUREMENT SYSTEM}

\section{A. Moorsom's system 185}

Traditionally, tonnage was related to the carrying capacity of the ship. Moorsom's [3] concept related tonnage to the total volume of enclosed spaces. Being the colonial power, the British maritime legislation spread throughout the world. During the second half of the 19th century, Moorsom's system was the basis for tonnage measurement around the world, though the rules varied from one jurisdiction to another [4].

\section{B. Suez Canal Rules 1873[5]}

Initially the net register tonnage was used as a basis for Suez Canal Company tolls. Since the revenue of Suez Canal was inadequate to meet the expenses and owing to the questionable propelling power deduction for steamers, gross register tonnage was adapted as the basis from July 1872, leading to higher charges. Shipping companies and owners opposed this change. Thus, an international tonnage commission, formed to resolve the issue, adopted separate rules for Suez Canal tonnage in 1873 at Constantinople. It was expected that the 1873 rules would be adopted by the countries represented at Constantinople leading to a universal system. Separate rules for Suez Canal tonnage came into existence.

It is important here to cite the text of Annex 2 regulation for the measurement of tonnage recommended by the international tonnage commission assembled at Constantinople 1873: "General principles: The gross tonnage or total capacity of ships comprises the exact measurement of all spaces (without any exception) below the upper deck, as well as of all permanent covered and closedin erections on that deck".N. B. by permanent covered and closed- in erections on the upper deck are to be understood all those which are separated off by decks or coverings, or fixed partitions and therefore represent an increase of capacity which might be used for the stowage of merchandises, or for the berthing and accommodation of the passengers or of officers and crew[6].This text in the Constantinople convention is the philosophical basis for estimating the Suez Canal tonnage so far.

\section{Panama Canal Ad measurement system}

The tonnage measurement system used in the Panama Canal is known as: Panama Canal Universal measurement system (PC/UMS), following the rules of ITC- 1969, using its parameters to determine the total volume of a vessel with the additional variations established by the authority. The ACP ad measurement system for a full container vessel reflects the international standard for a container TEU. This measurement considers the full container carrying capacity of vessels (above and below deck). In October 2002, the Panama Canal Authority decided to charge container vessels in a new method based on TEU, since the PC/UMS net tonnage was not representing the earning or economic capacity of 
container vessels[7].

\section{International convention on Tonnage Measurement of ships, 1969 (ITC-69)}

The efforts for a uniform method materialized when the convention on tonnage measurement of ships (ITC- 69) was adopted at an international conference held in London from 27th May to 23 June 1969. It was the second successful attempt to introduce a universal tonnage measurement system. The first attempt in 1873, when the Maritime powers assembled at Constantinople and adopted the rules of Suez Canal measurement system.

ITC- 69 applies to ships above 24 meters long and came into force on 18th July 1982. A phase in period was given for the ships built before that date to retain the existing tonnage figures up to 18th July 1994, for a smooth transition to the new system. The Suez Canal and Panama Canal Company continued with their separate methods for tonnage measurement even after adopting (ITC- 69).150 states amounting to $98.9 \%$ of world tonnage have ratified the convention, as of 31th July 2010 [8]. Under ITC-69 the overall size and useful capacity of a ship are indicated by dimensionless figures, GT and NT respectively (instead of GRT and NRT under Moorson's system). Calculated based on the total molded volume of enclosed spaces and volume of cargo spaces[9].

Therefore, $\mathrm{GT}=\mathrm{K}, 1 \mathrm{~V}$, whereby $\mathrm{V}=$ Total Volume of all enclosed spaces in cubic meters, and $\mathrm{K} 1=\mathrm{a}$ coefficient as tabulated in appendix 2 (of the convention). This coefficient ranges from 0.22 to 0.32 for the smallest to the largest volumes and cares for results being similar to the former tonnage figures based on 100 cubic feet. For the calculation of NT, same coefficient is used together with the volume of cargo spaces, the depth and the draught. NT shall not be taken as less than 0.30 GT. Thus GT and NT are calculated independently[10].

\section{SUEZ CANAL TRANSIT FEES OF TRIPLE-E VESSELS}

The tonnage on which all dues and charges to be paid by vessels are assessed, is the net tonnage resulting from the system of measurement laid down by the international commission held in Constantinople in 1873, and duly entered, on the special tonnage certificate issued by the competent authorities in each country[11]. The containers on upper deck are considered as closed in spaces increasing the carriage capacity of the ship when situated over the main deck[12]. Tolls are calculated on the basis of Suez Canal net tonnage plus a Ratio specified for the number of tiers on the upper deck according to circular No. 3/2014 of Suez Canal are as follows:

\section{Northbound Container Vessels}

- $4 \%$ for vessels carrying one tier.

- $6 \%$ for vessels carrying two tiers.

- $8 \%$ for vessels carrying three tiers.

- $11 \%$ for vessels carrying four tiers.

- $15 \%$ for vessels carrying five tiers.

- $21 \%$ for vessels carrying six tiers.

An increase of $2 \%$ shall be applied for each tier in excess of six tiers, which means that a surcharge of $23 \%$ shall be applied on vessels carrying seven tiers and $25 \%$ surcharge if vessels carrying 8 tiers...etc.: South bound vessels, circular No. 2/2007 shall remain in force, for example container vessel carrying 8 tiers on deck shall pay $20 \%$ surcharge [13].

2. Southbound container vessel

- $2 \%$ for vessels carrying one tier.

- $4 \%$ for vessels carrying two tiers.

- $6 \%$ for vessels carrying three tiers.

- $8 \%$ for vessels carrying four tiers.

- $12 \%$ for vessels carrying five tiers.

- $16 \%$ for vessels carrying six tiers.

- $18 \%$ for vessels carrying seven tiers.

An increase of $2 \%$ shall be applied for each tier in excess of seven tiers, which means that a surcharge of $20 \%$ shall be applied on vessels carrying 8 tiers on deck....etc. 


\section{Example}

- Northbound transit

Triple- E" class transited Suez Canal from its gross tonnage $=200532$ tons. Net tonnage $=$ 180528 tons. Carrying 8 layers of containers on upper deck. So additional dues $25 \%$ are taxed, plus extra dues for escorting tugs and pilots. The total Canal dues were 932741 U.S \$. That means the transfer cost of TEU in Suez Canal is 64.4 U.S. \$. So the more TEU the ship carry the less cost are realized. Another triple- E class vessel's cost of TEU through the Suez Canal is 58.8 U.S $\$$.

\section{- Southbound Transit}

Cost of TEU transiting Suez Canal ranges between 56 and 59 U.S \$, according to the number containers the ship were transporting.

\section{- EMMA-MAERSK class vessel}

This type of container vessel capacity 15000 TEU, the cost of TEU for transiting Suez Canal was 71.8 U.S. $\$$ in case of $68 \%$ utilization.

Table 3. TEU fees in Suez Canal

\begin{tabular}{|c|c|}
\hline TEU Cost U.S. \$. & Utilization \\
\hline \multicolumn{2}{|c|}{ a- Triple- E Direction (Northbound): } \\
\hline 67.5 & $76.0 \%$ \\
\hline 64.5 & $80.4 \%$ \\
\hline 58.8 & $88.9 \%$ \\
\hline \multicolumn{2}{|c|}{ b- Triple- E Direction (Southbound): } \\
\hline 56.1 & $88.4 \%$ \\
\hline 59.1 & $86.0 \%$ \\
\hline 59.5 & $85.0 \%$ \\
\hline c- EMMA MAERSK Class (Southbound): & $68.0 \%$ \\
\hline
\end{tabular}

TEU transport Cost through Suez Canal decrease, the higher the numbers of TEU can the ship carry.

\section{ADVANTAGES GRANTED TO CONTAINER VESSELS}

- Allow to the vessel carrying 10 TEUs on the higher tier without calculating it as tier.

- If protuberance part of open TEUs on the last tier exceeds half height of container, then consider one tier.

- If the ship carries empty containers only, then Suez Canal dues shall be calculated as ballast, provided that containers carried be belonged to the owner or charters

\section{CONCLUSION}

- Container vessels represent the bulk of the Suez Canal revenues.

- There is correlation between mega projects and economics of scale.

- Varying utilization of mega container ship affect the cost of TEU transiting Suez Canal.

- The slot cost increase for diminishing utilization.

- The importance of tonnage measurement of a container ship in particular for its operating economics.

- The need to pay attention to the rules of tonnage measurement of ships in the maritime institutes and colleges of engineering (Departments of Ship Engineering).

- New Suez Canal will cut time of transiting, consequently affecting "Triple-E" economics by saving time.

\section{REFERENCES}

[1] The Journal of Commerce, March 4, vol. 14, No.5, 2013.

[2] Cullian, K \& Khanna, 'Economies of Scale in Large Container Ships. Journal of Transport Economics and Policies, March 2000, vol. 33. pp. 185- 207 e-journal: www.bath.ac.uk.

[3] George Moorsom, Secretary Board of Trade in Britain, the 1854 British Tonnage Rules, British Merchant Shipping Act of 1854.

[4] Corkhill, Michael, Andrew Moysa, 'The Tonnage Measurement of Ships', Fairplay Publication. London, 1980. 
[5] Lane, Frederic, Tonnage Medieval and Modern. The Economic History Review. Second series, pp.17 (2) (213-233) electronic version.

[6] Elsayed Hussein Galal,'The International Conflict over the Exploitation of Suez Canal (1869-1882) Arabic Edition', 1979, pp. 197- 292, General Egyptian Book organization.

[7] Suez Canal Authority: Rules of Navigation (2007), part. 4, p. 169.

[8] Aji Vasudevan, 'Tonnage Measurement of Ships: Historical Evolution, Current Issues and Proposals for the Way Forward', 2010, p. 21. World Maritime University, Malmo. Sweden.
[9] Architecture of Instruction and Delight, Ibid, pp. 43- 44.

[10] International Maritime Origination issues, IMO, 1982.

[11] International Maritime Origination issues, IMO, 1982. Op. Cit.

[12] Suez Canal Authority, Rules of Navigation (1995) p. 190.

[13] Architecture of Instruction and Delight, Ibid, Art. 98, pp. 194. 